https://doi.org/10.31470/2706-7904-2020-15-44-48

\title{
ЯН БОДУЕН ДЕ КУРТЕНЕ ПРО ЗВ'ЯЗОК МОВИ І МИСЛЕННЯ
}

\section{Jan Baudouin de Courtenay about the Connection of Language and Mentality}

\section{Volodymyr Glushchenko}

\author{
DSc. in Philology, Professor \\ Donbas State Pedagogical University (Ukraine) \\ sdpunauka@ukr.net \\ https://orcid.org/0000-0002-2394-4966
}

\section{Maryna Rudenko}

Ph.D. in Philology

Donbas State Pedagogical University (Ukraine)

marinarudenko2016@gmail.com

https://orcid.org/0000-0002-6587-3860

\begin{abstract}
In the presented article an attempt of a special complex linguistic and historiographical study of $J$. Baudouin de Courtenay's views according to the connection of language and mentality is done. The purpose of the paper is to reveal the issue of the connection of language and mentality in J. Baudouin de Courtenay's interpretation accounting studious of his predecessors and contemporaries (first, the scholars of the Leipzig and Moscow linguistic schools). According to the purpose and objectives of the research, an actualistic method has been used in the work, which allows to trace the development of the object in the past and to foresee some trends for future development grounded on modern knowledge. The main task of the research is to disclosure of the new, which Baudouin de Courtenay introduced into the study of psychosocial properties of language, a complete and objective studying of linguistic historiographical material, taking into account the continuity in the deepening of scientific knowledge of language. In particular, J. Baudouin de Courtenay put forward a concept of language knowledge along with «intuitive, contemplative, direct knowledge and scientific, theoretic knowledge». The material presented in the article proves that Baudouin de Courtenay gave a deeper and more profound analysis of the psychosocial nature of the language and social factors of its development than his contemporaries.
\end{abstract}

Key words: linguistic historiographical aspect, actualistic method, psychosocial phenomenon, connection of language and mentality, language knowledge. 


\section{Вступ}

Introduction

Фундатор Казанської лінгвістичної школи Ян (Іван Олександрович) Бодуен де Куртене (1845-1929) інтерпретував мову як психосоціальний феномен. У кінці XIX ст. - на початку XX ст. саме в працях цього видатного лінгвіста відповідне коло питань було розкрито найбільш докладно й аргументовано.

Погляди Яна Бодуена де Куртене на мову як на психосоціальний феномен, зокрема на зв'язок мови і мислення, у контексті мовознавства XIX ст. - 30-х pp. $\mathrm{XX}$ ст. частково (з акцентуванням уваги на окремих аспектах проблеми) розглянуто в працях М.С. Чемоданова (Чемоданов, 1956), Ф.М. Березіна (Березин, 1968), Л. Г. Зубкової (Зубкова, 2003), у публікаціях В.А. Глущенка та О.М. Абрамічевої (Глущенко, 1998; Глущенко \& Абрамічева, 2009). У пропонованій розвідці робиться спроба спеціального лінгвоісторіографічного дослідження проблеми в цілому, із узагальненням спостережень попередніх праць.

Мета наукової розвідки полягає в усебічному розкритті питання про зв'язок мови і мислення в інтерпретації Бодуена де Куртене з урахуванням студій його попередників і сучасників (насамперед учених Лейпцизької та Московської лінгвістичних шкіл).

Ми ставимо перед собою завдання показати те нове, що було внесене Бодуеном де Куртене у вивчення зазначеного питання, дослідити лінгвоісторіографічний матеріал максимально повно й об'єктивно, беручи до уваги наступність у поглибленні наукових знань про мову.

\section{Методологія дослідження Research Methodology}

Методологія дослідження грунтується на принципах історизму, причиновості, системності та загального зв'язку явищ. Відповідно до мети й завдань дослідження в роботі використано актуалістичний метод, що дає змогу за допомогою сучасних знань простежити розвиток об'єкта в минулому та передбачити деякі тенденції майбутнього розвитку. В історіографію мовознавства термін актуалістичний метод увів В.А. Глущенко (1998). У межах актуалістичного методу кожна концепція й методика розглядаються $з$ погляду того, що нового внесли лінгвісти в науку порівняно зі своїми попередниками та яке значення мали їхні праці для розв'язання розглядуваних проблем. Операційний компонент актуалістичного методу в працях з історіографії мовознавства становить сукупність таких прийомів і процедур: (а) аналіз джерел 
(лінгвістичних текстів); (б) синтез одержаних даних; (в) порівняння;

(г) абстрагування; (г) історико-наукова реконструкція, що посідає центральне місце серед прийомів та процедур і протистоїть так званій «асиміляції минулого», що виявляється в модернізації поглядів лінгвістів попередніх поколінь.

\section{Результати \\ Results}

Проблемі взаємозв'язку мови і мислення Бодуен де Куртене приділяв значну увагу. За його спостереженнями, у XVIII ст. вчені «пояснювали все переважно свідомістю й безперешкодною волею»; 3 часом перевага стала надаватися безсвідомому (де Куртене, 1963, т. 1: 62-63), що видається цілком виправданим:

«Психічні процеси є безсвідомими, але вони можуть стати усвідомленими» (де Куртене, 1963, т. 2: 66). «На певному ступені розвитку» (де Куртене, 1963, т. 1: 40) людина починає впливати на мову. Це виявляється в навчанні мови, у формуванні норм літературної мови, у виникненні штучних мов (де Куртене, 1963, т. 2: 140, 152).

Досліджуючи проблему взаємозв'язку мови і мислення, Бодуен де Куртене ішов за В. фон Гумбольдтом і О.О. Потебнею (Зубкова, 2003: 305-306); ураховував він і студії вчених Лейпцизької (Г. Пауль) та Московської (П. Ф. Фортунатов) лінгвістичних шкіл.

Погляди Бодуена де Куртене, як ми вважаємо, стали одним із джерел неогумбольдтіанства.

На думку Бодуена де Куртене, «мова була й є неодмінною умовою мислення» (де Куртене, 1963, т. 1: 227). Проте можливе й мислення «позамовне» (де Куртене, 1963, т. 2: 177). При цьому мислення має однакові закони в різних етносів (де Куртене, 1963, т. 1: 363). Водночас «мова зумовлює характер народного розуму» (де Куртене, 1963, т. 1: 71); вона може впливати на мислення «або прискорюючи, або сповільнюючи, або посилюючи, або ж пригнічуючи» (де Куртене, 1963, т. 2: 79).

Спираючись на вчення Гумбольдта про мову як своєрідний світогляд (де Куртене, 1963, т. 2: 71), Бодуен де Куртене висунув поняття мовного знання (Зубкова, 2003: 306). Учений вважав мову «особливим знанням»: це «третє знання», поряд із «знанням інтуїтивним, споглядальним, безпосереднім, i знанням науковим, теоретичним» (де Куртене, 1963, т. 2: 79).

Що ж таке мовне знання? Це «сприйняття й пізнання світу в мовних формах» (де Куртене, 1963, т. 2: 95). Мовне знання включає в себе «знання всіх галузей буття й небуття, усіх виявів світу, як матеріального, так і індивідуально-психічного й соціального (суспільного)» (де Куртене, 1963, т. 2: 312). При цьому «усі сторони життя 
перетворюються в психічні еквіваленти, в уявлення, що асоціюються 3 мовними уявленнями» (де Куртене, 1963, т. 2: 312). Як приклади дослідник розглядав систему відмінків, відбиття кількісних відношень у мові (де Куртене, 1963, т. 2: 79, 311).

Проте далеко не все позамовне отримує мовне вираження, при цьому «в одній мові відбиваються одні групи позамовних уявлень, в іншій - інші» (де Куртене, 1963, т. 2: 83).

Бодуен де Куртене розрізнював у мові «дві сторони, психічну й фізіологічну, церебрацію й фонацію, інакше кажучи: 1) мову в точному значенні цього слова і 2) вимову». Провідною стороною в цій єдності він уважав церебрацію: «Сутність мови становить, природно, тільки церебрація, тобто мозковий процес, успадкований і придбаний шляхом зоологічного розвитку й під впливом оточення, залученого до суспільного життя. Фонація, однак, необхідна як кінцевий знак церебрації, як сполучна ланка, що $є$ посередником між церебраціями різних індивідів, здатних спілкуватися за допомогою мови» (де Куртене, 1963, т. 1: 144). Церебрація - це, за Бодуеном де Куртене, внутрішня, центральна сторона мови, а фонація, чи говоріння, сторона зовнішня, периферична (де Куртене, 1963, т. 1: 212).

Підкреслюючи «важливість розрізнення чисто фонетичного (фізіологічного) i психічного елемента в мові» (де Куртене, 1963, т. 2: 51), Бодуен де Куртене висував вимогу «стояти на точці зору об’єктивно-психологічній, усебічно досліджувати психіку індивідів, що становлять певне мовне суспільство», «не нав'язувати мові не притаманних їй категорій», «дошукуватися того, що в ній дійсно існує» (де Куртене, 1963, т. 2: 52).

\section{Висновки \\ Conclusions}

Наведений матеріал свідчить, що Бодуен де Куртене значно більш глибоко й широко, ніж його сучасники, аналізував взаємозв'язок мови і мислення.

Перспективи подальших досліджень ми вбачаємо в розкритті шляхів розв'язання проблеми взаємозв'язку мови і мислення в лінгвістиці XX ст. - початку XXI ст.

\section{Література \\ References}

Березин, Ф. (1968). Очерки по истории языкознания в России (конец XIX-начало XX в.).

Москва: Языкознание.

Боуэн, де Куртене, Я. (1963). Избранные труды по общему языкознанию. (В 2-х т.). Москва:

Языкознание. 
Psycholinguistics in a Modern World - 2020. Proceedings of the 15th International Scientific and Practical Conference (Pereiaslav-Khmelnytskyi, 22-23 October, 2020)

Глущенко, В. (1998). Принциипи порівняльно-історичного дослідження в українському $i$ російському мовознавстві (70-і pp. XIX cm. - 20-і pp. XX cm.). Донецьк: Языкознание.

Глущенко, В., \& Абрамічева, О. (2009). Мова як психосоціальний феномен у працях учених Московської та Казанської шкіл. Вісник Львівського університету, 46(1),162-176.

Зубкова, Л. (2003). Общая теория языка в развитиие. Москва: Языкознание.

Чемоданов, М. (1956). Сравнительное языкознание в России: Очерк развития сравнительноисторического метода в русском языкознании. Москва: Языкознание. 